\title{
Video Article \\ Determination of Thermodynamic Properties of Alkaline Earth-liquid Metal Alloys Using the Electromotive Force Technique
}

\author{
Thomas P. Nigl ${ }^{1}$, Nathan D. Smith ${ }^{1}$, Timothy Lichtenstein ${ }^{1}$, Jarrod Gesualdi ${ }^{1}$, Kuldeep Kumar ${ }^{1}$, Hojong Kim ${ }^{1}$ \\ ${ }^{1}$ Department of Materials Science and Engineering, The Pennsylvania State University
}

Correspondence to: Hojong Kim at huk29@psu.edu

URL: https://www.jove.com/video/56718

DOI: doi: $10.3791 / 56718$

Keywords: Chemistry, Issue 129, Electromotive force, thermodynamic properties, alkaline-earth alloys, electrochemical separation, binary alloys, electromotive force method

Date Published: $11 / 3 / 2017$

Citation: Nigl, T.P., Smith, N.D., Lichtenstein, T., Gesualdi, J., Kumar, K., Kim, H. Determination of Thermodynamic Properties of Alkaline Earthliquid Metal Alloys Using the Electromotive Force Technique. J. Vis. Exp. (129), e56718, doi:10.3791/56718 (2017).

\section{Abstract}

A novel electrochemical cell based on a $\mathrm{CaF}_{2}$ solid-state electrolyte has been developed to measure the electromotive force (emf) of binary alkaline earth-liquid metal alloys as functions of both composition and temperature in order to acquire thermodynamic data. The cell consists of a chemically stable solid-state $\mathrm{CaF}_{2}-\mathrm{AF}_{2}$ electrolyte (where $\mathrm{A}$ is the alkaline-earth element such as $\mathrm{Ca}, \mathrm{Sr}$, or $\mathrm{Ba}$ ), with binary $\mathrm{A}-\mathrm{B}$ alloy (where $\mathrm{B}$ is the liquid metal such as $\mathrm{Bi}$ or $\mathrm{Sb}$ ) working electrodes, and a pure $\mathrm{A}$ metal reference electrode. Emf data are collected over a temperature range of $723 \mathrm{~K}$ to $1,123 \mathrm{~K}$ in $25 \mathrm{~K}$ increments for multiple alloy compositions per experiment and the results are analyzed to yield activity values, phase transition temperatures, and partial molar entropies/enthalpies for each composition.

\section{Video Link}

The video component of this article can be found at https://www.jove.com/video/56718/

\section{Introduction}

Electromotive force (emf) measurements can directly determine the partial molar Gibbs free energy change of a chemical reaction and provide accurate thermodynamic properties such as activity, partial molar enthalpy, and partial molar entropy ${ }^{1}$. The acquisition of thermochemical data is crucial to a variety of research topics in the materials community, from the refinement of multi-component phase diagrams, to the experimental validation of first-principle materials modeling, to the synthesis of new intermetallic species with advantageous properties. Recently, Kim et al. utilized emf measurements to assess the viability of using liquid metal electrodes to separate alkaline-earth species from molten salt electrolytes ${ }^{2}$.

Electrochemical separation using molten salts (e.g., $\mathrm{LiCl}-\mathrm{KCl})$ is a promising technology for separating uranium and transuranic metals from used nuclear fuel for recycling ${ }^{3}$. As used fuel is processed as an anode in the molten salt, fission products with lower standard reduction potentials than uranium are oxidized and accumulate in the molten salt as dissolved ions (e.g., $\mathrm{Ba}^{2+}, \mathrm{Sr}^{2+}, \mathrm{Cs}^{+}$, and rare-earth metal cations) ${ }^{4}$. Consequently, the molten salt electrolyte must be periodically replaced and/or processed further to separate the accumulated fission products ${ }^{4}$. Of particular concern are alkali/alkaline-earth fission products $\left(\mathrm{Ba}^{2+}, \mathrm{Sr}^{2+}\right.$, and $\left.\mathrm{Cs}^{+}\right)$because these ions exhibit the lowest standard reduction potentials among the constituent cations, making them difficult to separate from the molten salt solution.

However, Lichtenstein et al. recently demonstrated that barium exhibits low thermodynamic activity in liquid bismuth $\left(8.7 \times 10^{-12}\right.$ at barium mole fraction $x_{\mathrm{Ba} \text { (in Bi) }}=0.05,1,123 \mathrm{~K}$ ), implying strong atomic interactions between barium and bismuth ${ }^{5}$. Kim et al. observed that these interactions caused a shift in the deposition potentials of barium ions into a liquid bismuth electrode $\left(-3.74 \mathrm{~V}\right.$ to $-2.49 \mathrm{~V} \mathrm{vs}$. $\left.\mathrm{Cl}^{-} / \mathrm{Cl}_{2}(\mathrm{~g})\right)$, resulting in a preferential deposition of barium from the electrolyte solution $\left(\mathrm{BaCl}_{2}-\mathrm{LiCl}_{-} \mathrm{CaCl}_{2}-\mathrm{NaCl}, 16-29-35-20 \mathrm{~mol} \%\right)$ at $773-973 \mathrm{~K}^{6}$. This shift in deposition potential could be leveraged by using liquid metal electrodes to selectively separate alkali/alkaline-earth fission products from the electrolyte used for electrochemical processing of used nuclear fuel. To determine the viability of separating alkali/alkaline-earth fission products from molten salt electrolyte, the thermodynamic properties of these elements in the prospective liquid metals (e.g., $\mathrm{Bi}, \mathrm{Sb})$ must be determined.

In previous studies, Delcet et al. utilized coulometric titration to determine the thermodynamic properties of binary alloys (e.g., Ba-Bi, Ba-Sb,

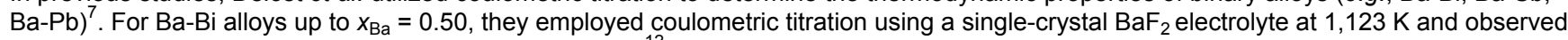
comparable activity values of barium in bismuth $\left(2.4 \times 10^{-12}\right.$ at $\left.x_{\mathrm{Ba} \text { (in } \mathrm{Bi})}=0.05,1,123 \mathrm{~K}\right)$. However, it was reported that the results were inaccurate due to the uncertainty regarding barium content in the binary alloys. Barium metal is highly reactive and soluble in its halide salts $(\sim 15$ mol $\%$ in $\mathrm{BaCl}_{2}$ at 1,163 K), which can cause increased electronic conduction in the halide salt at higher temperatures and lead to inaccurate compositional accounting during coulometric titration. To determine the thermodynamic properties (e.g., excess partial molar Gibbs free energy, partial molar enthalpy, partial molar entropy) of binary alloys containing highly reactive elements, the emf method described in this protocol was used. 
Thermochemical properties of binary alloys can be determined by measuring the equilibrium cell potential $E_{\text {cell }}($ i.e., emf) of an alloy (A-B) relative to the reference potential of the pure metal $A$. Then, the cell potential is directly related to the change in partial molar Gibbs free energy (or chemical potential) of the cell reaction according to the Nernst relation $\left(\Delta \bar{G}_{\mathrm{A}}=-z F E_{\text {cell }}\right)$ ).

For emf measurements of alkaline-earth alloys in this work, the fluoride-ion conducting $\mathrm{CaF}_{2}$ is chosen as the base electrolyte because the $\mathrm{Ca}^{2+} / \mathrm{Ca}$ redox potential $\left(E^{0}=-5.59 \mathrm{~V}\right)$ is more negative than other alkaline-earth redox potentials $\left(e . g ., E_{\mathrm{Ba} / \mathrm{Ba}}^{0}{ }^{2+}=-5.52 \mathrm{~V}, E_{\mathrm{Ba} / \mathrm{Ba}}^{0}{ }^{2+}=-5.52 \mathrm{~V}\right.$ versus $\mathrm{F}^{-} / \mathrm{F}_{2}(\mathrm{~g})$ at $\left.873 \mathrm{~K}\right)$ in the fluoride system ${ }^{8}$. This implies that $\mathrm{CaF}_{2}$ is more chemically stable than the other alkaline-earth fluoride $A F_{2}(A$ $=\mathrm{Sr}$ or $\mathrm{Ba}$ ), and that $\mathrm{Ba}^{2+}$ or $\mathrm{Sr}^{2+}$ ions are the electroactive species in the $\mathrm{CaF}_{2}-\mathrm{BaF}_{2}$ and $\mathrm{CaF}_{2}-\mathrm{SrF}_{2}$ electrolyte, respectively. Utilizing the high stability of $\mathrm{CaF}_{2}$, which minimizes side reactions with $\mathrm{Ba}$ or $\mathrm{Sr}$ alloys as well as the ionic conductivity of $\mathrm{CaF}_{2}$ at elevated temperatures, the single-phase binary $\mathrm{CaF}_{2}-\mathrm{AF}_{2}$ electrolyte was successfully employed to accurately measure the emf of binary alkaline earth-liquid metal alloys. Confirmation of the formation of the single-phase binary electrolyte is confirmed with x-ray diffraction (XRD) analysis in Figure $1^{9}$.

To measure the cell potential of an alkaline-earth alloy, the following electrochemical cell was implemented using a solid-state binary $\mathrm{CaF}_{2}-\mathrm{AF}_{2}$ $\left(97 \mathrm{~mol} \% \mathrm{CaF}_{2}, 3 \mathrm{~mol}^{\circ} \mathrm{AF}_{2}\right.$ ) electrolyte ${ }^{10}$ :

$A(s)\left|\mathrm{CaF}_{2}-\mathrm{AF}_{2}\right| \mathrm{A}($ in $\mathrm{B})$,

where the pure alkaline-earth metal $A(A=\mathrm{Ca}, \mathrm{Sr}$, or $\mathrm{Ba})$ acts as the reference electrode $(\mathrm{RE})$, solid $\mathrm{CaF}_{2}-\mathrm{AF}_{2}$ as the electrolyte, fixed composition A-B alloys as working electrodes (WE), and $\mathrm{B}$ is a candidate liquid metal such as $\mathrm{Bi}$ or $\mathrm{Sb}$. The half-cell reactions in the electrochemical cell are:

WE: $A^{z+}+z e^{-}=A($ in $B)$

$R E: A^{z+}+z e^{-}=A(s)$,

and the overall cell reaction is:

$A(s)=A($ in $B)$.

where $e^{-}$is an electron exchanged in the cell reactions and $z$ is the number of electrons exchanged ( $z=2$ for alkaline-earth elements). For this overall reaction, the change in partial molar Gibbs free energy of the $\mathrm{A}$ metal, $\Delta \bar{G}_{\mathrm{A}}$, is given by:

$\Delta \bar{G}_{\mathrm{A}}=\bar{G}_{\mathrm{A}(\mathrm{in} \mathrm{B})}-\bar{G}_{\mathrm{A}(\mathrm{s})}^{0}=R T \ln \left(a_{\mathrm{A}}\right)$,

where $\bar{G}_{\mathrm{A}(\text { in B) }}$ is the partial molar Gibbs free energy of A metal in the metal $\mathrm{B}, \bar{G}_{\mathrm{A}(\mathrm{s})}^{0}$ is the standard Gibbs free energy of pure A metal, $R$ is the ideal gas constant, $T$ is the temperature in Kelvin, and $a_{\mathrm{A}}$ is the activity of $\mathrm{A}$ in the metal $\mathrm{B}$. The measured cell emf, $E_{\text {celll, }}$ is directly related to the change in partial molar Gibbs free energy of $A$ by the Nernst equation,

$E_{\text {cell }}=-\frac{\Delta \bar{G}_{\mathrm{A}}}{z F}=-\frac{R T}{z F} \ln \left(a_{\mathrm{A}}\right)$

where $F$ is the Faraday constant.

\section{Protocol}

\section{Fabrication of Electrochemical Cell Components}

\section{Fabrication of the binary $\mathrm{CaF}_{2}-\mathrm{AF}_{2}$ electrolyte}

1. Calculate the mass required for each component of the binary electrolyte for a $350.0 \pm 5.0 \mathrm{~g} \mathrm{mixture} \mathrm{with} 97 \mathrm{~mol} \% \mathrm{CaF}_{2}$ and $3 \mathrm{~mol} \%$ $\mathrm{AF}_{2}$ (e.g., $333.4 \mathrm{~g}$ of $\mathrm{CaF}_{2}$ and $16.6 \mathrm{~g}$ of $\mathrm{SrF}_{2}$ ).

2. Measure out and pour the salt mixture into a $1.5 \mathrm{~L}$ plastic bottle, along with approximately $1.3 \mathrm{~kg}$ of yttria-stabilized zirconia milling media ( $3 \mathrm{~mm}$ diameter) and $25.0 \pm 0.1 \mathrm{~g}$ of polyvinyl alcohol (PVA, organic binder). Then add isopropyl alcohol (IPA) until the bottle is $4 / 5$ full. Close the bottle and manually shake its contents for approximately $1 \mathrm{~min}$ to evenly distribute the components of the mixture.

3. Place the plastic bottle with the salt mixture on the ball mill (two-rollers, 12.5 " length). Set the speed of the ball mill to 250 revolutions per minute (RPM) and mill for $24 \mathrm{~h}$.

4. Pour the mixture through a sieve (10 mesh) into a pan to separate the milling media and the salt mixture. Using a squeeze bottle, rinse the sieve lightly with $10 \mathrm{~mL}$ of IPA to capture the remaining mixture.

5. Dry the ball-milled homogeneous mixture in a fume hood for $\sim 24 \mathrm{~h}$ and then grind the mixture into a fine powder using a mortar and pestle.

NOTE: If the drying process needs to be accelerated, the pan can be placed on a hot plate set to $373 \mathrm{~K}$.

6. Measure out $130.0 \pm 1.0 \mathrm{~g}$ of electrolyte powder and load the powder uniformly into a pellet die $(75 \mathrm{~mm}$ diameter, $60 \mathrm{~mm}$ height).

7. Using a die press, uniaxially press the powder with $30 \mathrm{MPa}$ of pressure for 2 mins to form a green pellet $75 \mathrm{~mm}$ in diameter and $17 \mathrm{~mm}$ thickness. To remove the pellet from the pellet die, invert the pellet die, place a stainless-steel ring (101 mm outer diameter (OD), 35 $\mathrm{mm}$ height, $4.8 \mathrm{~mm}$ thickness) centered on top of the pellet die with the pellet centered within the ring. Carefully press the pellet die punch with $\sim 1.0$ bar of pressure to remove the pellet from the die.

8. Use a small drill bit ( $1 \mathrm{~mm}$ diameter) to create tapping holes $(\sim 0.5 \mathrm{~mm}$ in depth) in the green pellet, one in the center and six evenly spaced $25.4 \mathrm{~mm}$ between drill centers. Then use the large drill bit $(11.2 \mathrm{~mm}$ diameter) to manually drill seven wells centered on the tapping holes, each one approximately $12 \mathrm{~mm}$ deep (approximately $3 / 4$ of the way through the pellet).

9. For each of the six electrolyte caps required, measure out $4.5 \pm 0.5 \mathrm{~g}$ of electrolyte powder and load the powder uniformly into a pellet die (19 $\mathrm{mm}$ diameter, $50 \mathrm{~mm}$ height).

10. Uniaxially press the electrolyte powder with $7.5 \mathrm{MPa}$ for $1 \mathrm{~min}$ into a green pellet $19 \mathrm{~mm} \times 10 \mathrm{~mm}$ in diameter and thickness. To remove the pellet from the pellet die, invert the pellet die, place a stainless-steel ring ( $37.5 \mathrm{~mm} \mathrm{OD,} 30 \mathrm{~mm}$ height, $3.5 \mathrm{~mm}$ thickness) 
centered on top of the pellet die with the pellet centered within the ring. Carefully press the pellet die punch with $\sim 1.0$ bar of pressure to remove the pellet from the die. Use a small drill bit $(2 \mathrm{~mm}$ diameter) to manually drill a center hole through each cap.

NOTE: Green pellets from 1.1.8. and 1.1.10. are ready for sintering to form a single-phase solid electrolyte in the following steps.

11. For each large electrolyte pellet and set of six small electrolyte caps, lightly cover an alumina plate $(10 \mathrm{~cm}$ diameter, $4.65 \mathrm{~mm}$ thick $)$ with coarse alumina powder to facilitate the separation of the sintered pellet from the alumina plate. Place the electrolyte pieces on top of the alumina powder such that they do not touch each other.

12. Place the above assembly from 1.1.11 in a high temperature box furnace. Sinter the pieces with the following heating profile: $393 \mathrm{~K}$ for $12 \mathrm{~h}$ to remove moisture, $823 \mathrm{~K}$ for $12 \mathrm{~h}$ to burn out the PVA, and $1,273 \mathrm{~K}$ for $3 \mathrm{~h}$ to sinter, all with heating rates of $5 \mathrm{~K} / \mathrm{min}$. Then cool to $298 \mathrm{~K}$ at a rate of $2.5 \mathrm{~K} / \mathrm{min}$.

\section{Fabrication of the alkaline-earth alloy electrodes}

1. In an argon-filled glovebox, measure out the mass of the two components of the binary alloy, with a combined mass of at least $6.0 \mathrm{~g}$ (e.g., $5.6 \mathrm{~g}$ of $\mathrm{Bi}$ and $0.4 \mathrm{~g}$ of $\mathrm{Ba}$ for $\mathrm{Ba}-\mathrm{Bi}$ alloy at barium mole fraction $\mathrm{x}_{\mathrm{Ba}}=0.10$ ). Place in a tray and remove from the glovebox. NOTE: Reactive metals are stored under mineral oil to prevent oxidation. To remove the mineral oil, sonicate the alkaline-earth metal pieces in acetone for $10 \mathrm{~s}$.

2. Place all the metal pieces on the center of the arc-melter stage and secure the stage.

3. Pull vacuum on the chamber for 3 min until a vacuum of approximately -1.0 bar (gauge pressure) is achieved, and then fill with argon to 0.0 bar (gauge pressure). Repeat this procedure at least three times to ensure an inert argon atmosphere during the arc-melting process.

4. Close the eye-protection shield on the arc-melter unit and turn on the current to create a stable electric arc between the stage and the tungsten tip of the arc-melter. Melt the metal pieces into a single homogeneous piece by exposing the pieces to the electric arc. Sufficient melting can be confirmed by the absence of observable separate phases in the alloy piece.

NOTE: If highly reactive elements are being melted, using a high current for longer than $\sim 5 \mathrm{~s}$ can result in vaporization of material and cause inconsistencies in alloy composition.

5. After melting the pieces into a single alloy, turn off the current and the arc-melter. Unscrew the stage from the chamber, flip the alloy, and screw the stage back into the chamber of the arc-melter. Repeat 1.2.3 - 1.2.5 three times to form a homogeneous alloy.

6. After re-melting the alloy, unscrew the stage from the chamber again and break or cut the alloy into approximately 3 to 6 smaller pieces. Place the pieces on the stage and screw the stage back into the chamber of the arc-melter. Re-melt the pieces into a single piece according to steps 1.2.3 - 1.2.5.

7. Allow the system to cool for $3-5 \mathrm{~min}$. Detach the stage from the arc-melter system, and store the alloy in a plastic bag. Place the bag under an inert argon atmosphere (e.g., glovebox) until the final electrochemical cell assembly.

NOTE: For each experiment, two reference electrode alloy pieces and up to four working electrode alloy pieces of different compositions will be required.

\section{Preparation of the tungsten electrical leads and thermocouple}

1. Cut 6 tungsten wires ( $1 \mathrm{~mm}$ diameter) $46 \mathrm{~cm}$ in length. Manually sand along the length of each wire to remove surface contaminants, such as an oxide layer, using 100 grit emery paper. Clean the wire surface using wipes wetted with acetone.

2. Insert the wire into an alumina tube $(6.35 \mathrm{~mm}$ diameter, $30.5 \mathrm{~cm}$ long) that will prevent electrical shorting between the electrical leads and stainless-steel test chamber during electrochemical measurement. Leave approximately $12.7 \mathrm{~cm}$ at one end (bottom) as bare wire for making contact with the electrodes, and $2.5 \mathrm{~cm}$ at the other end (top) for electrical contact with the potentiostat leads.

3. Mix approximately $3 \mathrm{~g}$ of quick cure epoxy and hardener for $1 \mathrm{~min}$ using the end of a wood applicator stick.

4. With the wire in the tube, apply approximately $3 \mathrm{~g}$ of the epoxy to the top end of the tube to seal it. Lay the tube and wire vertically using a laboratory stand and allow the epoxy to cure for $15 \mathrm{~min}$. Repeat for each tungsten wire (electrical lead).

5. Insert the bottom end of a $45 \mathrm{~cm}$ thermocouple (type-K) into the top of a new $30.5 \mathrm{~cm}$ long alumina tube and seal the gap between the thermocouple and alumina tube using a quick cure epoxy similar to Step 1.3.4, leaving $\sim 5 \mathrm{~mm}$ of the thermocouple exposed at the top. Allow the epoxy to cure for $15 \mathrm{~min}$.

\section{Assembly of the Electrochemical Cell}

\section{Cleaning of the electrochemical cell assembly components}

1. Before the assembly of the electrochemical cell, thoroughly sand the inner surface of the stainless-steel test chamber with 100 grit emery paper until there is no visible contamination on the stainless-steel surfaces. Clean the test chamber, chamber cap, and alumina crucible $(8.2 \mathrm{~cm}$ diameter, $3.0 \mathrm{~cm}$ height) using de-ionized water and rinse with IPA.

2. Sonicate the parts of the vacuum fittings and the o-rings in isopropanol for $\sim 10$ min and allow them to dry inside the drying oven at $\sim 373 \mathrm{~K}$. Apply a thin coating of vacuum grease to o-rings for improved vacuum quality. Then move all electrochemical setup components into an argon filled glovebox for assembly.

\section{Loading of the electrochemical cell assembly}

1. Place the sintered electrolyte (step 1.1) at the center of the alumina crucible located in the test chamber carrier.

2. Load enough electrode material into each well such that the top of the material is flush with the surface of the electrolyte. Fill two wells with reference electrode materials (e.g., Ba-Bi $\left.\left(x_{\mathrm{Ba}}=0.05\right)\right)$ of identical composition. Then fill four wells with working electrode material, each well having a different composition (Figure 2). In this step, shape arc-melted electrode materials close to the cylindrical shape of the electrolyte wells and drill a center through hole ( $2 \mathrm{~mm}$ diameter) for electrical lead insertion using machining tools (e.g., mini-lathe, drill bits, etc.).

NOTE: Minimize the exposure duration of samples to air to mitigate oxidation. Extensive oxidation is indicated by the presence of a non-lustrous (dull) surface layer on the samples. To remove the oxide layer, sand the surface of the sample(s) using 100 grit emery paper and clean with a dry wipe.

3. Insert the electrical lead assembly (tungsten wire with alumina tube in 1.3) through the vacuum fitting port of the chamber cap, the baffle plates of the chamber, the hole in an electrolyte cap, and in the hole in an alloy electrode. Repeat this procedure for all six 
electrodes. Then insert the thermocouple through the last vacuum fitting port and into the seventh well at the center. Firmly touch the electrolyte surface with the alloy. A complete assembly is shown in Figure 2 and Figure 3.

NOTE: Each tungsten wire must firmly touch the electrolyte surface. If the alloy is too brittle to be machined, the tungsten wire can be held pressed against the alloy by pressing the wire against the alloy and securing its placement by tightening the vacuum fitting on the vacuum fitting port.

4. Place the large o-ring in the groove of the top of the stainless-steel vacuum chamber. Carefully lower the assembled electrochemical cells into the test chamber. Securely tighten all vacuum-seal components and the clamp of the test chamber.

3. Removing moisture and oxygen from electrochemical cell assembly for emf measurement

1. Load the assembled test chamber into a crucible furnace. Place two overlapping layers of fiberglass insulation around the exposed surface of the vacuum chamber that is not in the furnace to ensure a uniform temperature distribution in the electrochemical cell and prevent the failure of the epoxy seals at the top of the test chamber.

2. Attach the cooling water lines to the cooling tube inlet and outlet ports on the test chamber (Figure 3 and Figure 4).

3. Attach the vacuum/argon line to the inlet port of the test chamber and close the outlet port valve. Evacuate the test chamber until the vacuum gauge reading is below 10 mtorr.

NOTE: If the vacuum level cannot achieve less than 10 mtorr, check seal components of the test chamber, including o-rings, clamps, tube fittings, and epoxy seals.

4. Under active vacuum ( $<10 \mathrm{mtorr}$ ), increase the furnace temperature to $373 \mathrm{~K}$ at a heating rate of $5 \mathrm{~K} / \mathrm{min}$ and hold for $10 \mathrm{~h}$; increase to $543 \mathrm{~K}$ at the same heating rate and hold for $10 \mathrm{~h}$. NOTE: The drying procedure takes about $20 \mathrm{~h}$.

5. Once the above drying procedure is completed, purge the chamber with ultra-high purity argon. Repeat evacuation $(<10 \mathrm{mtorr})$ and argon purge $(\sim 1 \mathrm{~atm})$ at least three times to ensure an inert atmosphere for operation at elevated temperatures.

6. After the last argon purge, open both the inlet and outlet valves of the test chamber and adjust the flow meter to maintain continuous argon flow of $50.0 \mathrm{~mL} / \mathrm{min}$ at ambient atmospheric chamber pressure $(\sim 1 \mathrm{~atm})$.

\section{Electrochemical Measurements}

1. Establishing electrical contact between cell assembly and potentiostat

1. Connect the counter electrode cable and the reference electrode cable from the potentiostat once the furnace has reached $543 \mathrm{~K}$. NOTE: Each electrode cable (e.g., reference electrode, counter electrode, working electrode, sensing electrode cables) has a plug at the end of the cable that allows electrical connection.

2. Attach an alligator clip to the end of the reference electrode cable from the potentiostat and clip it onto the electrical lead of the reference electrode from the cell assembly.

3. Plug in five working electrode cables, one into each port 1 through 5 , on the multiplexing (MUX) switch box. Attach an alligator clip to each working electrode cable and connect each alligator clip to the electrical lead for each working electrode from the electrochemical cell assembly, allowing for sequential voltage measurements of the other five electrodes relative to the reference electrode.

NOTE: One working electrode should possess the same composition as the reference electrode. The voltage difference between these two identical electrodes should be approximately zero and should be monitored during the entire measurement. A voltage difference less than $2-3 \mathrm{mV}$ indicates the stability and reliability of the reference electrode system for accurate emf measurements.

4. Attach one end of a ground cable to the stainless-steel test chamber and plug the other end directly into the ground port of an electrical outlet.

NOTE: This procedure effectively suppresses the electrical noise coming from the furnace heating elements because the stainlesssteel test chamber serves as a Faradaic cage during the electrochemical measurements.

5. Create a program using electrochemical software to measure the open circuit potential (OCP) for each working electrode sequentially using the potentiostat software under galvanostatic mode.

NOTE: The custom program, available by request, measures and records the OCP of each working electrode, rotating through each working electrode sequentially over time, with each rotation lasting for $15 \mathrm{~min}$. The program should rotate through the set of working electrodes to record OCP measurements at each temperature increment.

6. Increase the furnace temperature from $543 \mathrm{~K}$ to $1,073 \mathrm{~K}$ at $5.0 \mathrm{~K} / \mathrm{min}$, where the electrolyte becomes ionically conductive for emf measurements.

NOTE: At $1,073 \mathrm{~K}$, the reference electrode should be fully molten to establish stable electrical contact with the electrolyte and electrical lead for enhanced stability of reference electrode potentials during the emf measurements.

2. Setting the thermal profile of the furnace for thermal cycling during emf measurement

NOTE: The temperature range is contingent upon the phase transition behavior of the electrode compositions (e.g., melting temperature) as well as the reactivity of the alloy composition. A typical temperature profile for the study of the Ba-Bi and $\mathrm{Sr}-\mathrm{Bi}$ alloy systems, between 723 and $1,073 \mathrm{~K}$, is given below.

1. Program the furnace controller to decrease the furnace temperature from $1,073 \mathrm{~K}$ to $723 \mathrm{~K}$ and to increase from $723 \mathrm{~K}$ to $1,073 \mathrm{~K}$ in $25 \mathrm{~K}$ intervals at a ramping rate of $\pm 5 \mathrm{~K} / \mathrm{min}$. At each temperature step (each $25 \mathrm{~K}$ interval), hold the temperature for $1-2 \mathrm{~h}$ to allow components to reach thermal and electrochemical equilibrium.

NOTE: Thermal equilibrium is reached once the cell temperature remains steady within $\pm 1 \mathrm{~K}$ at each temperature step as denoted by the thermocouple data displayed by the associated data acquisition (DAQ) system.

\section{Temperature and emf data collection}

1. Record the temperature of the electrochemical cell during the entire thermal cycle using a thermocouple DAQ system; include the upper and lower temperature limits of the furnace program and the type of thermocouple. Begin the emf measurement program at the same time as the temperature recording.

NOTE: The OCP measurement of each working electrode is measured against the reference electrode. The OCP measurement between the two reference electrodes should be less than 2-3 $\mathrm{mV}$. 
2. Use the cell temperature and the OCP measurements of each working electrode to determine the emf values of each alkaline earthliquid metal alloy as a function of temperature. The OCP values at each temperature are the emf values between the working and reference electrodes.

\section{Representative Results}

Figure 5 displays emf measurements made upon cooling and reheating an electrochemical cell: $\mathrm{Ba}-\mathrm{Bi}\left(x_{\mathrm{Ba}}=0.05\right)\left|\mathrm{CaF} F_{2}-\mathrm{BaF} F_{2}\right| \mathrm{Ba}-\mathrm{Bi}\left(x_{\mathrm{Ba}}=0.05\right.$, 0.10 , and 0.20 ), where a Ba-Bi alloy at $x_{\mathrm{Ba}}=0.05$ serves as the reference electrode ${ }^{5}$.

The potential difference between the two identical Ba-Bi alloys at $x_{\mathrm{Ba}}=0.05$ remains less than $2 \mathrm{mV}$ during the entire measurement, demonstrating the stability and reliability of the reference electrode. For alloy compositions at $x_{\mathrm{Ba}}=0.10$ and $x_{\mathrm{Ba}}=0.20$, a symmetric emf profile is obtained during the heating and cooling cycles, indicating reproducible emf values during thermal cycling. At each temperature step (each 25 $\mathrm{K}$ interval), the cell temperature and the cell emf value reach thermal and electrochemical steady-state in less than $1-2 \mathrm{~h}(\text { Figure } 5)^{5}$.

To determine thermodynamic properties of the $\mathrm{Ba}-\mathrm{Bi}$ alloys against the standard state of pure $\mathrm{Ba}(\mathrm{s})$, the emf values of the $\mathrm{Ba}-\mathrm{Bi}\left(x_{\mathrm{Ba}}=0.05\right)$ alloy reference electrode must be calibrated with respect to pure $\mathrm{Ba}$. The emf values of the reference electrode with respect to pure $\mathrm{Ba}$ are determined by using a separate electrochemical cell: $\mathrm{Ba}(\mathrm{s})\left|\mathrm{CaF}_{2}-\mathrm{BaF}_{2}\right| \mathrm{Ba}-\mathrm{Bi}\left(x_{\mathrm{Ba}}=0.05\right)$ and the results are presented in Figure 6 . Using the linear fit of this measurement at $\mathrm{X}_{\mathrm{Ba}}=0.05$ (Figure 6 ), the emf values of $\mathrm{Ba}-\mathrm{Bi}$ alloys $\left(E_{\text {cell }}\right)$ are determined relative to pure Ba metal ${ }^{5}$.

The emf values of $\mathrm{Ba}-\mathrm{Bi}$ alloys, relative to pure $\mathrm{Ba}(\mathrm{s})$, are plotted as a function of temperature at each electrode composition, as shown in Figure 7 for selected $\mathrm{Ba}-\mathrm{Bi}$ alloys $\left(x_{\mathrm{Ba}}=0.05-0.25\right)^{5}$. From linear fits of the emf data plotted versus temperature, the change in partial molar entropy was calculated using the following thermodynamic equation:

$\Delta \bar{S}_{\mathrm{Ba}}=-\left(\frac{\partial \Delta \bar{G}_{\mathrm{Ba}}}{\partial T}\right)_{\mathrm{P}}=2 F\left(\frac{\partial E_{\text {cell }}}{\partial T}\right)_{\mathrm{P}}$

and the partial molar enthalpy of barium in bismuth can be calculated using thermodynamic relations such as the Gibbs-Helmholtz equation, as shown below. The results are summarized in Table $1^{5}$.

$\Delta \bar{H}_{\mathrm{Ba}}=-\left(\frac{\partial\left(\Delta \bar{G}_{\mathrm{Ba}} / T\right)}{\partial T}\right)_{p}=2 F T^{2}\left(\frac{\partial\left(E_{\text {cell }} / T\right)}{\partial T}\right)_{p}$

The activity of barium was also determined using the collected emf values and the Nernst equation:

$\ln \left(a_{\mathrm{Ba}}\right)=-\frac{2 F}{R T} E_{\text {cell }}$.

The results are summarized in Table $2^{5}$

Emf values for $\mathrm{Ba}-\mathrm{Bi}$ alloys $\left(\mathrm{x}_{\mathrm{Ba}}=0.05-0.80\right)$ were also used to determine the phase transition temperatures for each alloy composition. In conjunction with differential scanning calorimetry (DSC) phase transition data, inductively coupled plasma atomic emission spectroscopy (ICPAES) composition data, similar to that displayed in Table $\mathbf{3}^{12}$, and crystal structure data from XRD analysis, emf data were used to refine the most recent Ba-Bi phase diagram reported by Okamoto (Figure 8) ${ }^{5,11}$. 


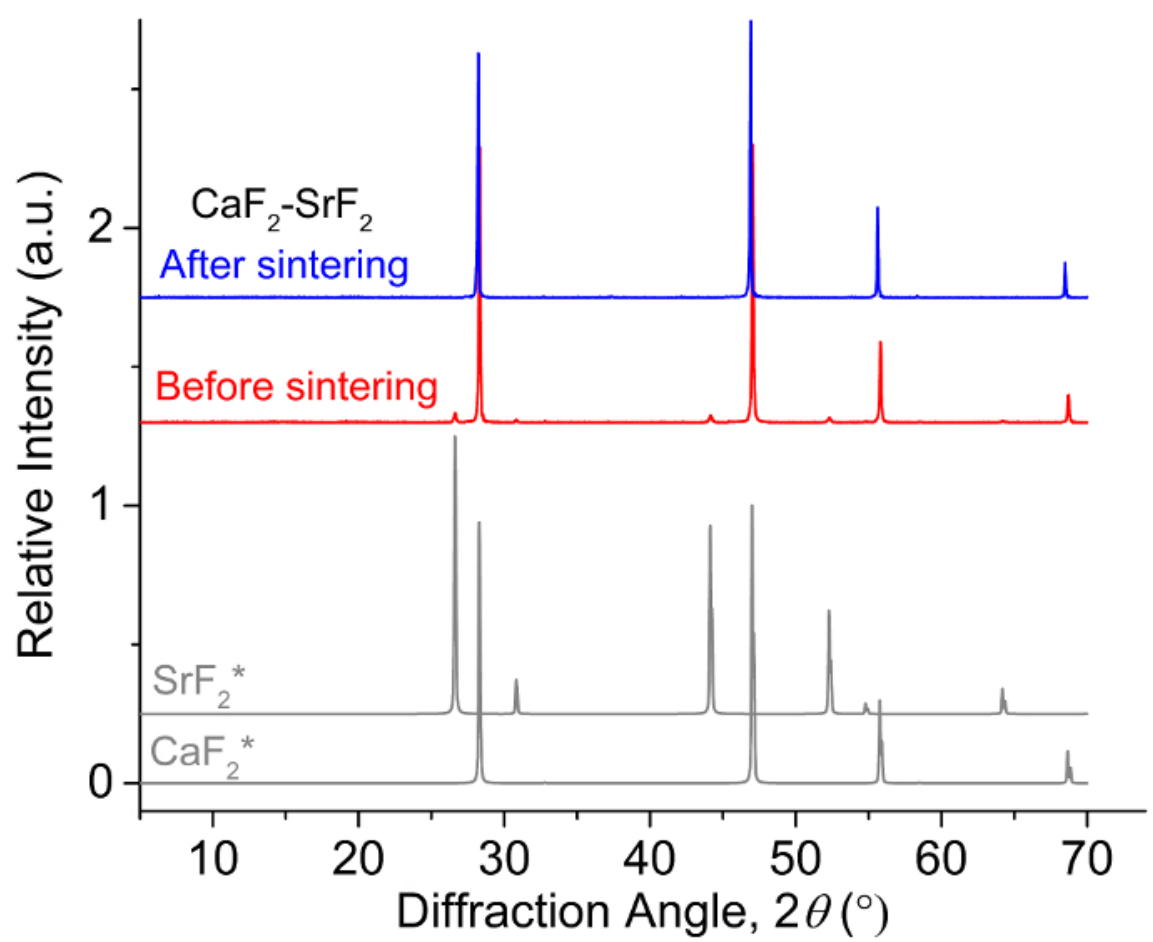

Figure 1: Single-phase $\mathrm{CaF}_{2}-\mathrm{SrF}_{2}$ electrolyte $\mathrm{XRD}$ spectra. $\mathrm{XRD}$ spectra (normalized to the most intense peak for each spectrum) of CaF $2^{-}$ $\mathrm{SrF}_{2}$ electrolyte before and after sintering. Pure $\left(^{*}\right) \mathrm{CaF}_{2}$ and $\mathrm{SrF}_{2}$ diffraction patterns are provided for comparison. This figure has been modified from Smith et al. ${ }^{9}$ Please click here to view a larger version of this figure.

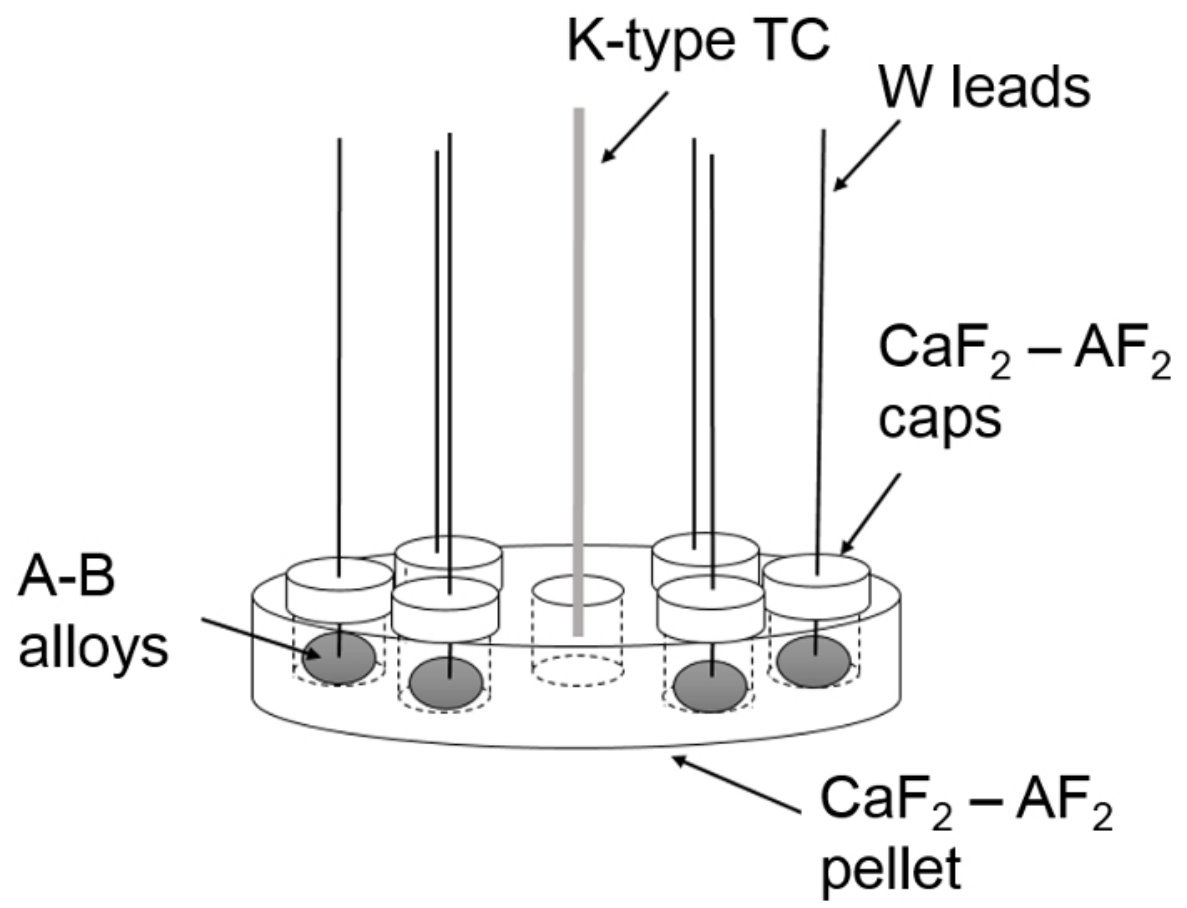

Figure 2: Electrochemical cell of A-B alkaline earth-liquid metal alloys. A schematic of the electrochemical cell assembly used for emf measurements with electrolyte, electrolyte caps, electrode materials, tungsten leads, and thermocouple (TC). Two of the 6 A-B alloys are reference electrodes and 4 are working electrodes. Please click here to view a larger version of this figure. 


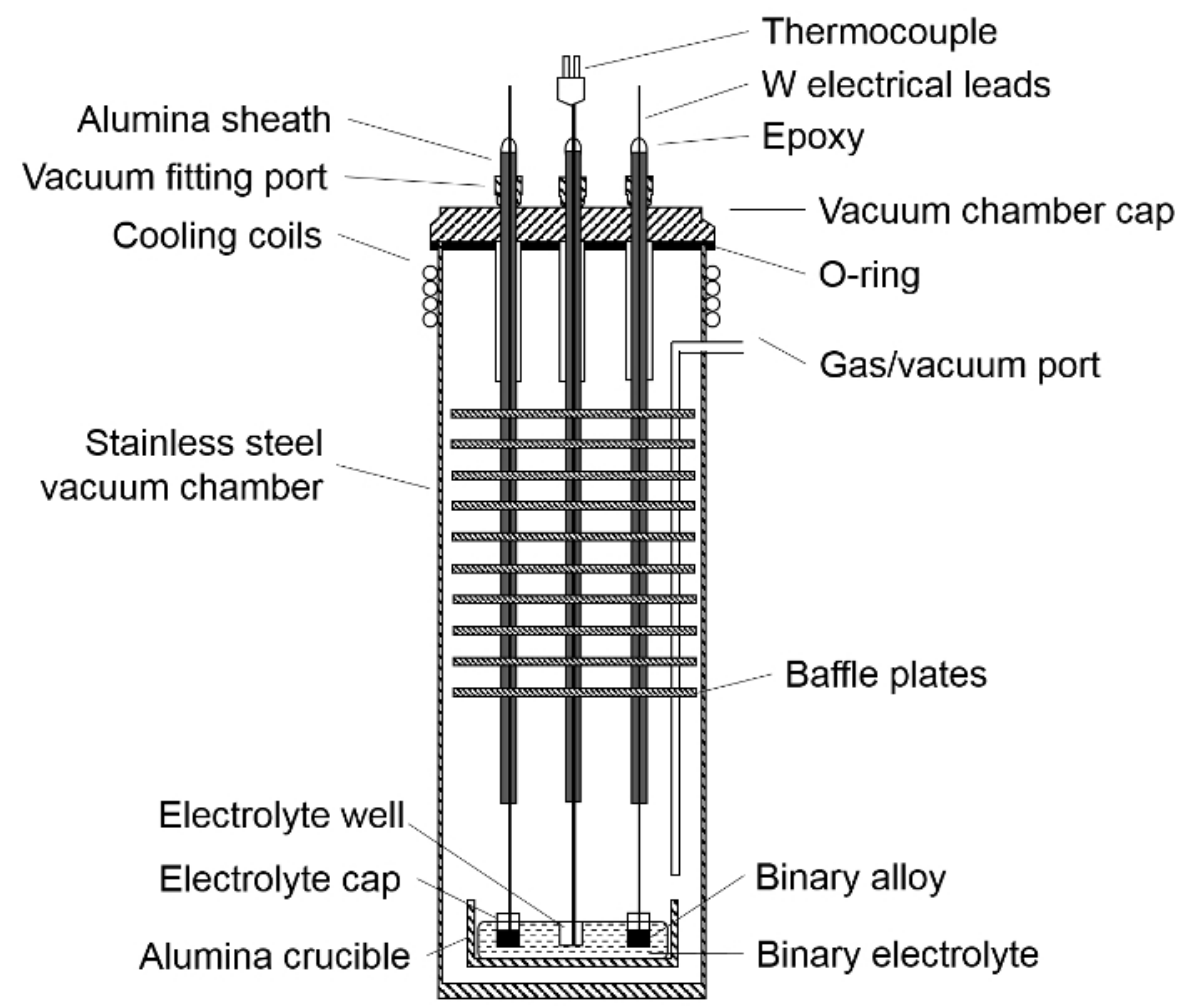

Figure 3: Electrochemical setup for emf measurements. An illustration of the electrochemical cell components and the associated components for proper operating conditions. Please click here to view a larger version of this figure.

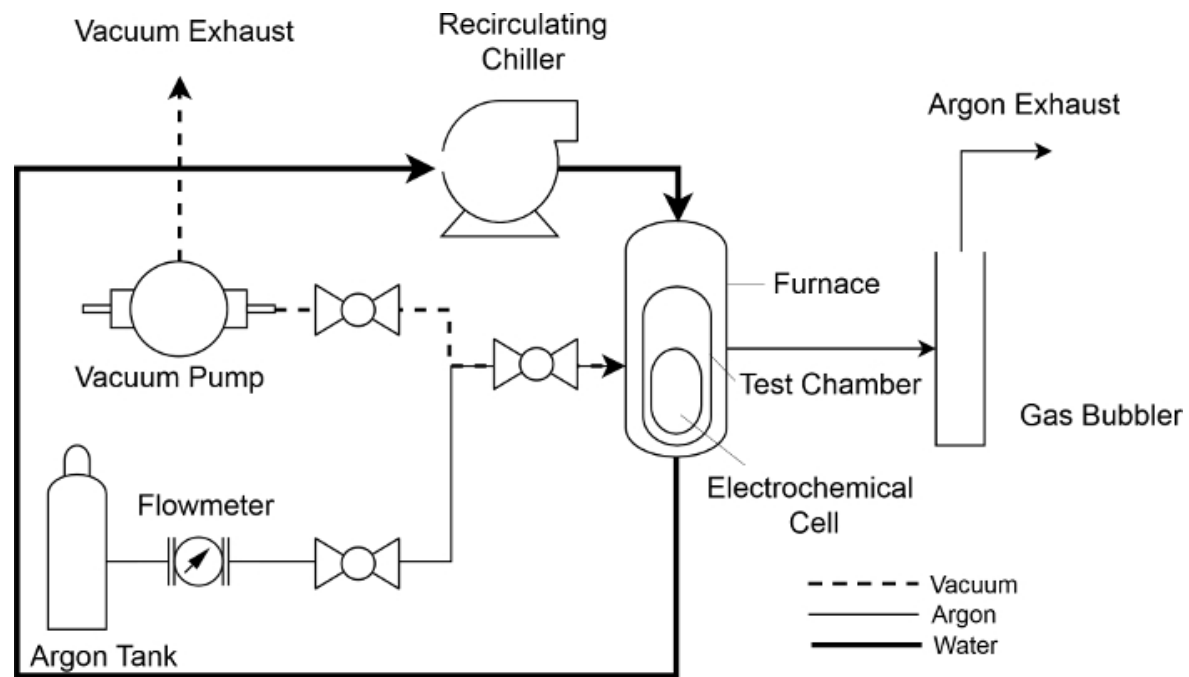

Figure 4: Instrumentation diagram of experimental setup. A schematic of cooling water (solid, bold), argon (solid, thin), and vacuum (dashed) fluid flow through the emf measurement system. Please click here to view a larger version of this figure. 


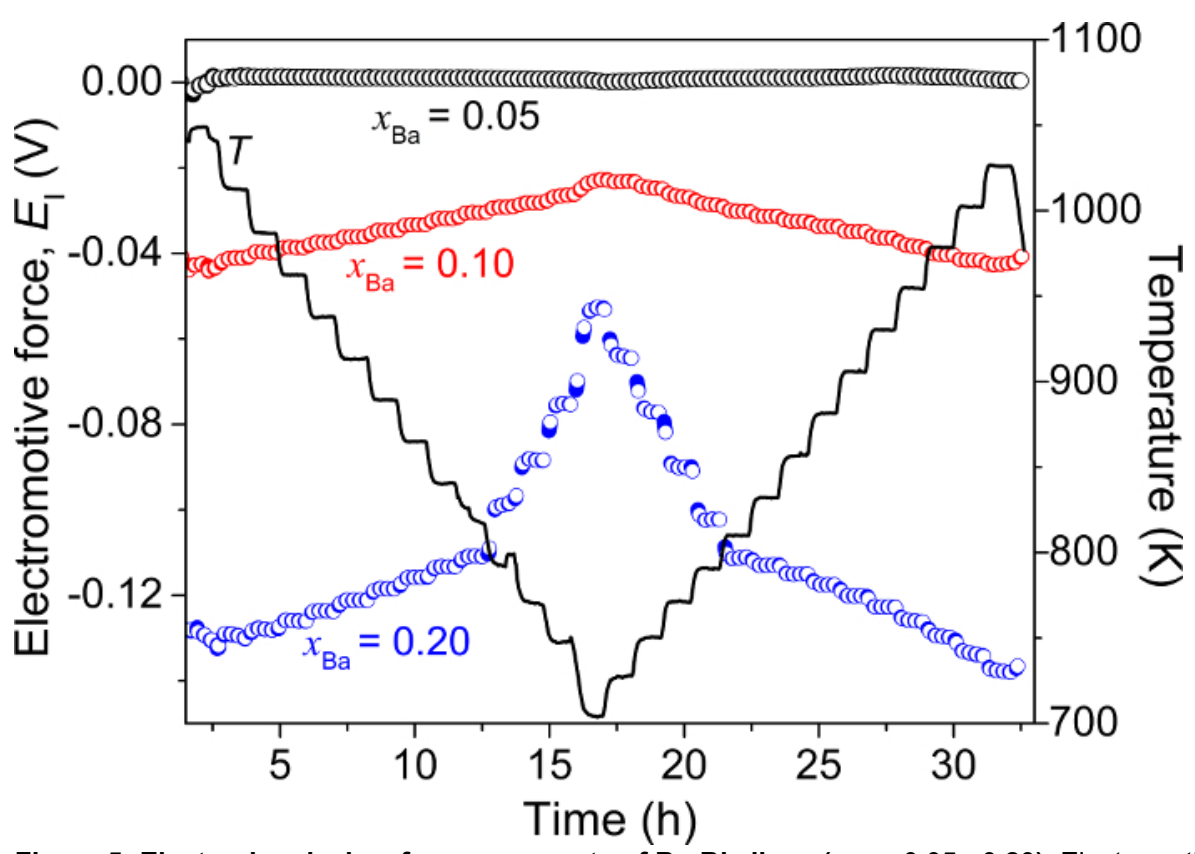

Figure 5: Electrochemical emf measurements of $\mathrm{Ba}-\mathrm{Bi}$ alloys $\left(x_{\mathrm{Ba}}=\mathbf{0 . 0 5}-\mathbf{0 . 2 0}\right)$. Electromotive force $\left(E_{1}\right)$ and temperature measured as a function of time upon cooling and reheating a $\mathrm{Ba}-\mathrm{Bi}\left(x_{\mathrm{Ba}}=0.05\right)\left|\mathrm{CaF}_{2}-\mathrm{BaF}_{2}\right| \mathrm{Ba}-\mathrm{Bi}\left(x_{\mathrm{Ba}}=0.05,0.10\right.$, and 0.20$)$ cell. This figure has been modified from Lichtenstein et al. ${ }^{5}$ Please click here to view a larger version of this figure.

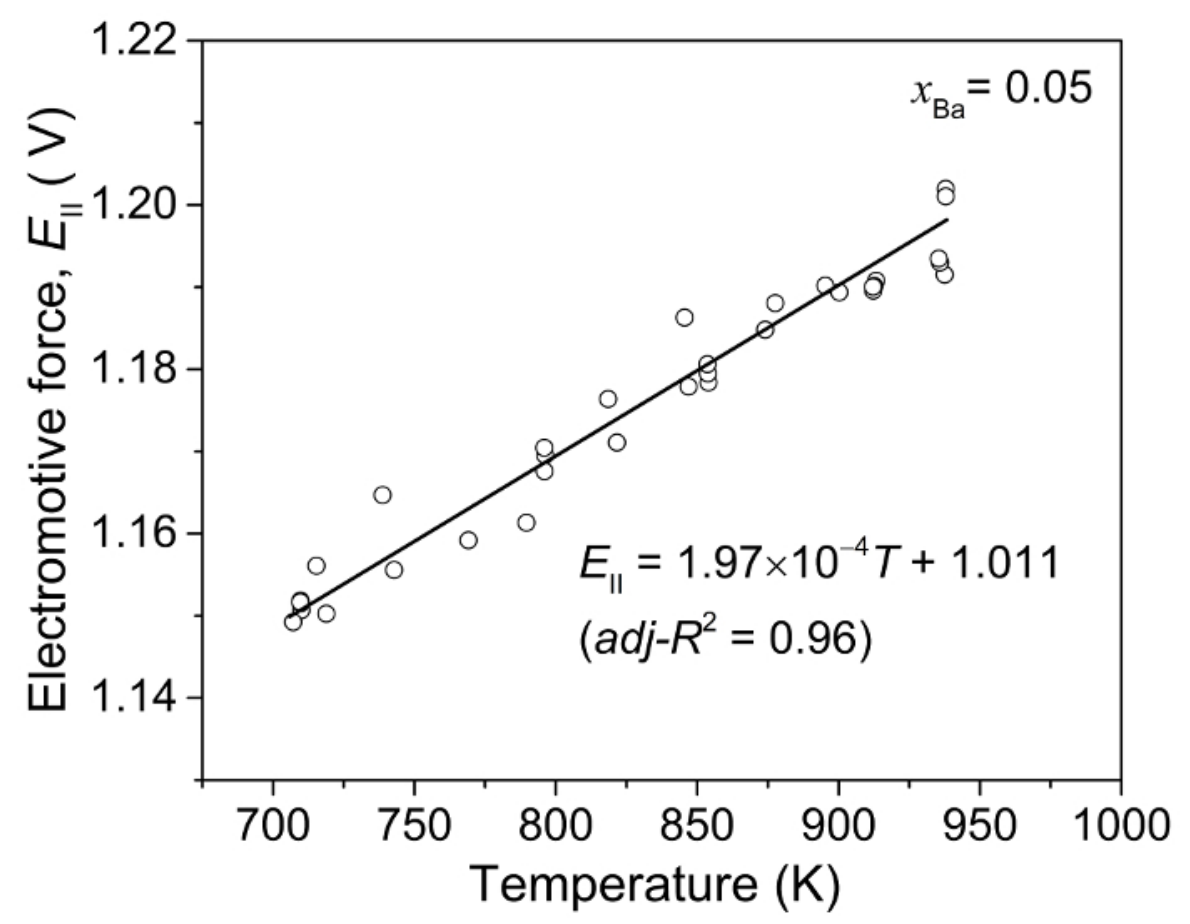

Figure 6: Pure $\mathrm{Ba}$ vs. Ba-Bi alloy $\left(x_{\mathrm{Ba}}=0.05\right)$ emf value calibration. Electromotive force $\left(E_{\| 1}\right)$ measured as a function of temperature using a $\mathrm{Ba}(\mathrm{s})\left|\mathrm{CaF}_{2}-\mathrm{BaF}_{2}\right| \mathrm{Ba}-\mathrm{Bi}\left(x_{\mathrm{Ba}}=0.05\right)$ cell. This figure has been modified from Lichtenstein et al. ${ }^{5}$ Please click here to view a larger version of this figure. 


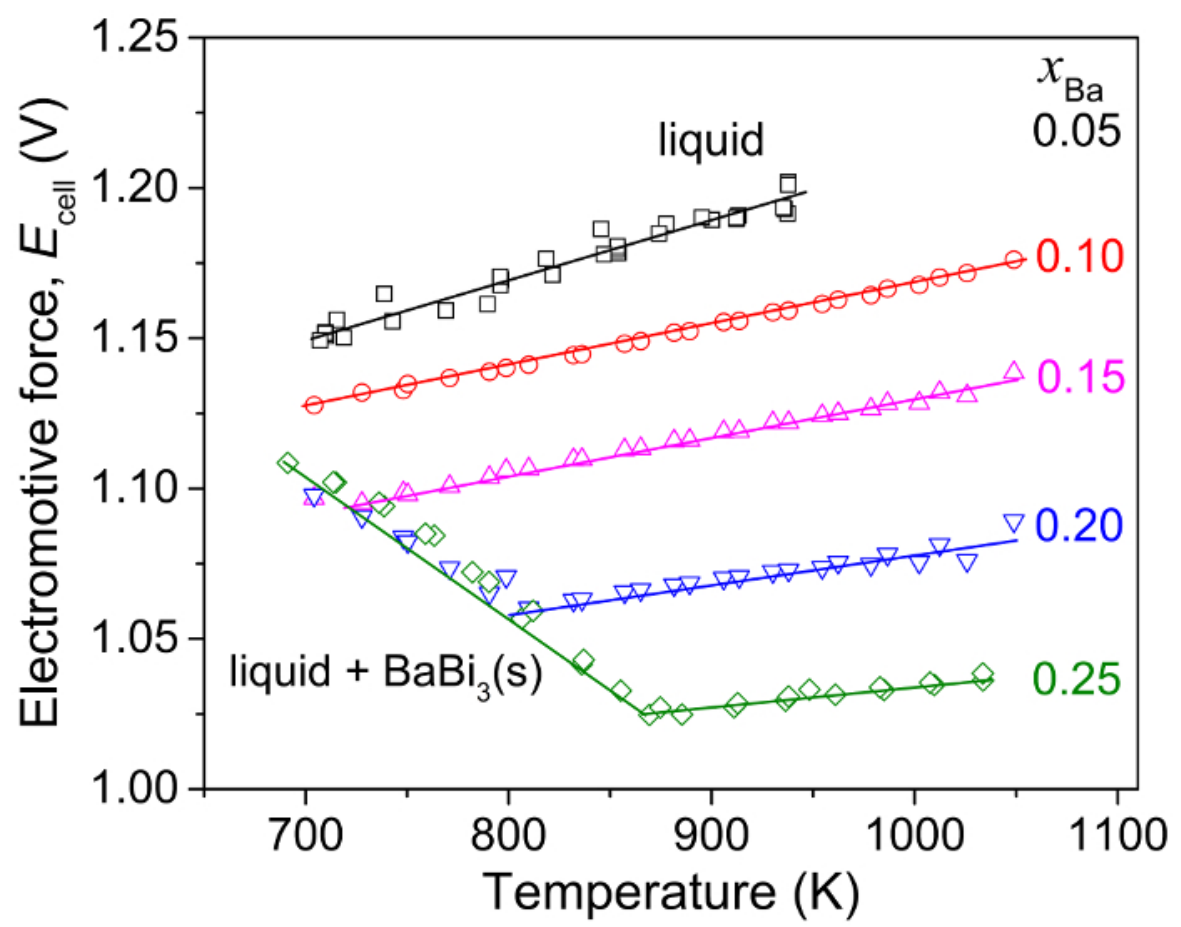

Figure 7: Emf measurements of Ba-Bi alloys $\left(x_{\mathrm{Ba}}=0.05-0.25\right)$. Electromotive force $\left(E_{\text {cell }}\right)$ as a function of temperature for Ba-Bi alloys at $x_{\mathrm{Ba}}$ $=0.05,0.10,0.15,0.20$, and 0.25 based on $\mathrm{Ba}(\mathrm{s})\left|\mathrm{CaF}_{2}-\mathrm{BaF}_{2}\right| \mathrm{Ba}-\mathrm{Bi}\left(X_{\mathrm{Ba}}=0.05-0.25\right)$, where solid lines represent linear fits. This figure has been modified from Lichtenstein et al. ${ }^{5}$ Please click here to view a larger version of this figure.

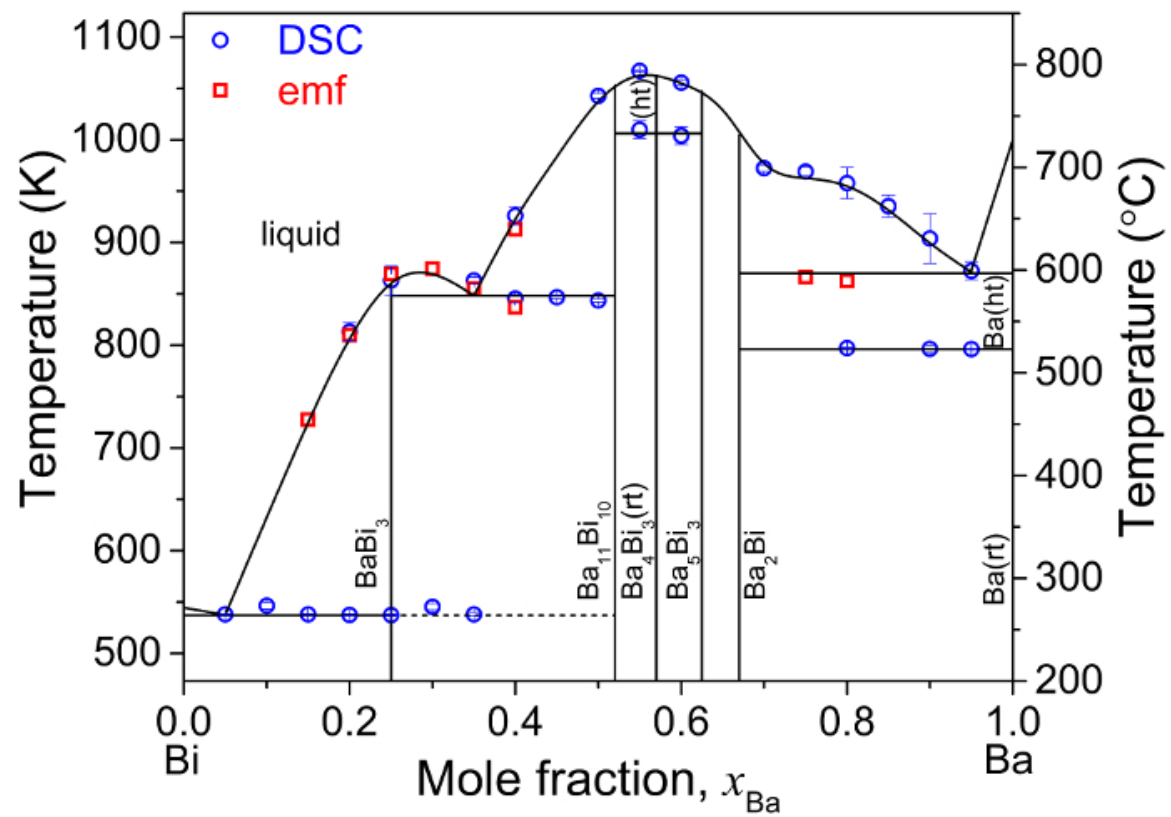

Figure 8: Ba-Bi phase diagram. Experimentally determined Ba-Bi phase diagram based upon emf measurements in complement with DSC and XRD characterization of Ba-Bi alloys, where ( $\mathrm{rt}$ ) and (ht) represent room temperature and high temperature, respectively. This figure has been modified from Lichtenstein et al. ${ }^{5}$ Please click here to view a larger version of this figure. 


\begin{tabular}{|l|l|l|l|l|l|}
\hline $\mathbf{X}_{B a}$ & $\mathbf{T}(\mathrm{K})$ & $\partial \mathrm{E}_{\mathrm{cell}} / \partial T\left(\mu \mathbf{V ~ K}^{-1}\right)$ & $\partial\left(\mathrm{E}_{\text {cell }} / T\right) / \partial(\mathbf{1 / T})(\mathbf{m V})$ & $\Delta \overline{\mathrm{S}}_{B a}\left(\mathbf{J ~ m o l}^{-1} \mathbf{K}^{-1}\right)$ & $\Delta \overline{\mathrm{H}}_{B a}\left(\mathbf{k J ~ m o l}^{-1}\right)$ \\
\hline 0.05 & $707-938$ & $197 \pm 6$ & $1011 \pm 5$ & 38 & -195.1 \\
\hline 0.1 & $704-1048$ & $137 \pm 1$ & $1031 \pm 1$ & 26.4 & -199 \\
\hline 0.15 & $728-1048$ & $125 \pm 2$ & $1005 \pm 2$ & 24.1 & -193.9 \\
\hline 0.2 & $809-1048$ & $94 \pm 7$ & $984 \pm 6$ & 18.1 & -189.9 \\
\hline 0.25 & $881-1048$ & $73.4 \pm 5$ & $961 \pm 5$ & 14.2 & -185.4 \\
\hline 0.25 & $704-881$ & $-480 \pm 14$ & $1448 \pm 13$ & -92.6 & -279.4 \\
\hline
\end{tabular}

Table 1: Thermodynamic properties of Ba-Bi alloys $\left(x_{\mathrm{Ba}}=0.05-\mathbf{0 . 2 5}\right)$. Change in partial molar entropies $\left(\Delta \overline{\mathrm{S}}_{B a}\right)$ and partial molar enthalpies $\left(\triangle \overline{\mathrm{H}}_{\mathrm{B} a}\right)$ for $\mathrm{Ba}-\mathrm{Bi}$ alloy compositions $\mathrm{X}_{\mathrm{Ba}}=0.05$ to $\mathrm{x}_{\mathrm{Ba}}=0.25$ calculated from linear fits of emf values, where the slopes and intercepts are $\partial\left(E_{\text {cell }} / T\right)$ and $T^{2} \partial\left(\left(E_{\text {cell }} / T\right) / \partial T\right)$, respectively. This table has been modified from Lichtenstein et al. ${ }^{5}$

\begin{tabular}{|c|c|c|c|c|c|c|}
\hline \multirow[t]{2}{*}{$\mathrm{X}_{\mathrm{Ba}}$} & \multicolumn{3}{|l|}{$E(\mathrm{~V})$} & \multicolumn{3}{|l|}{ In $a_{\mathrm{Ba}}$} \\
\hline & $773 \mathrm{~K}$ & $873 \mathrm{~K}$ & $973 \mathrm{~K}$ & $773 \mathrm{~K}$ & $873 \mathrm{~K}$ & $973 \mathrm{~K}$ \\
\hline 0.05 & 1.164 & 1.183 & 1.203 & -35 & -31.5 & -28.7 \\
\hline 0.10 & 1.137 & 1.15 & 1.164 & -34.1 & -30.6 & -27.8 \\
\hline 0.15 & \begin{tabular}{|l|}
1.101 \\
\end{tabular} & 1.114 & 1.127 & -33 & -29.6 & -26.9 \\
\hline 0.20 & 1.075 & 1.066 & 1.076 & -32.2 & -28.3 & -25.7 \\
\hline 0.25 & 1.075 & 1.027 & 1.032 & -32.2 & -27.3 & -24.6 \\
\hline
\end{tabular}

Table 2: Measured emf values $(E)$ and the natural log of activity of barium in bismuth (In $\left.a_{\mathrm{Ba}}\right)$. The measured emf values of Ba-Bi alloys $\left(x_{\mathrm{Ba}}=0.05-0.25\right)$ versus $\mathrm{Ba}(\mathrm{s})$ and the natural log of activity of barium in bismuth at $773 \mathrm{~K}, 873 \mathrm{~K}$, and $973 \mathrm{~K}$. This table has been modified from Lichtenstein et al. ${ }^{5}$

\begin{tabular}{|l|l|}
\hline Mole fraction, $x_{B a}$ & Measured \\
\hline Nominal & 0.03 \\
\hline 0.03 & 0.05 \\
\hline 0.05 & 0.09 \\
\hline 0.10 & 0.14 \\
\hline 0.15 & 0.20 \\
\hline 0.20 & 0.25 \\
\hline 0.25 & 0.30 \\
\hline 0.30 & \\
\hline
\end{tabular}

Table 3: Nominal and measured barium content of Ba-Sb binary alloys. The nominal and measured barium content of Ba-Sb binary alloys. Barium content of Ba-Sb alloys was confirmed using inductively coupled plasma atomic emission spectroscopy (ICP-AES). This table has been modified from Lichtenstein et al. ${ }^{12}$

\section{Discussion}

The emf cell in this work uses a $\mathrm{CaF}_{2}$-based solid electrolyte and electrode materials at fixed compositions, compared to an emf cell that uses a coulometric titration technique where the electrode composition is changed at a constant temperature. With coulometric titration, the electrode composition is determined by Faraday's law, assuming perfect coulombic efficiency. However, highly reactive alkaline-earth metals are moderately soluble (e.g., $\mathrm{Ba} \sim 15 \mathrm{~mol} \%$ solubility in $\mathrm{BaCl}_{2}$ ) in their own halide salts, which can promote electronic conduction through the electrolyte and prevent accurate control of the composition of the electrode during coulometric titration ${ }^{7,13}$. The electrochemical cell in this work operates with electrode materials at fixed compositions, thus eliminating uncertainty in compositional accounting by coulometric titration, and enables accurate emf measurements of alkaline-earth alloys. Furthermore, the unique electrochemical cell in this work measures the emf values of four alloy compositions simultaneously within the same experiment to accelerate the evaluation of the thermodynamic properties over a wide range of compositions and temperatures.

As the arc-melter is used to fabricate the binary alloys, it is possible that the final composition of the alloys can deviate from the initial composition due to the high temperature of the electric arc and the high vapor pressures of the metals. To accurately report the emf-temperature relationship of the binary alloys, their composition was confirmed using inductively coupled plasma atomic emission spectroscopy (ICP-AES), as shown in Table 3 for the Ba-Sb system ${ }^{12}$.

Before drying the electrochemical cell components according to step 2.3.4, difficulties in obtaining high-quality vacuum ( $<10$ mtorr) may occur. The o-ring in the vacuum chamber setup may not be seated correctly in its stainless-steel groove. There may also be a gap in the epoxy seals of 
the alumina tubes, to which additional epoxy may be applied to plug possible leaks. During emf measurements, if the electrical leads lose contact with the A-B alloys and large fluctuations in emf values are observed, contact may be re-established with the alloys by gently twisting the alumina tube, thereby wetting the liquid alloy to the lead.

Occasionally the emf values may exhibit a large hysteresis between the cooling and heating cycles. In general, a hysteresis of emf values between cooling/heating cycles may originate from (1) the degradation of electrolyte with reactive electrode compositions, especially at high alkaline-earth concentrations; (2) the degradation of electrode materials due to vaporization at elevated temperatures and oxidation with the residual oxygen inside the test chamber; or (3) non-equilibrium phase behavior of electrode materials, including undercooling effects and the formation of metastable phases during the cooling cycle.

When the degradation reaction between the electrode and the electrolyte is evident, the experimental set-up can be modified to mitigate the degradation of the electrochemical cell by decreasing the maximum operating temperature. In the presence of undercooling effects, emf values obtained during the heating cycle may be utilized in determining equilibrium thermodynamic properties. When the formation of metastable phases causes a hysteresis in emf measurements, the phase behavior of electrode materials requires scrutiny through complementary techniques, e.g., structural characterization by XRD, analysis of phase constituents by scanning electron microscopy (SEM) with energydispersive spectroscopy (EDS), and phase transition temperatures by DSC. Phase transition data may also be difficult to obtain with the described emf measurement technique above $1,223 \mathrm{~K}$, as the $\mathrm{CaF}_{2}-\mathrm{AF}_{2}$ electrolyte may begin to degrade.

The emf measurement technique in this work can be used to determine the empirical thermodynamic properties of binary alkaline earth-liquid metal alloys, including activity, partial molar entropy, partial molar enthalpy, and phase transition temperatures. These thermodynamic data are utilized as an experimental basis for refining binary phase diagrams of alkaline-earth alloys with complementary techniques (XRD, DSC, and $\mathrm{SEM})$, as exemplified in Figure $\mathbf{8}^{5}$. Based on the activity values of each alkaline-earth metal $(\mathrm{A}=\mathrm{Ca}, \mathrm{Ba}$, and $\mathrm{Sr})$ in liquid metals $(\mathrm{B}=\mathrm{Bi}$ and $\mathrm{Sb})$, the strength of atomic interactions between alkaline-earth elements and liquid metals can be leveraged to electrochemically separate out alkaline-earth fission products from molten salt solutions.

\section{Disclosures}

The authors have no conflicts of interest to disclose concerning the material in the publication.

\section{Acknowledgements}

This work was supported by the US Department of Energy, Office of Nuclear Energy's Nuclear Energy University Programs (Award No. DENE0008425); Integrated University Program Graduate Fellowship (Award No. DE-NE0000113); and the Ministry of Trade, Industry \& Energy, Republic of Korea, the Energy Efficiency \& Resources Core Technology Program of the Korea Institute of Energy Technology Evaluation and Planning (KETEP) (No. 20142020104190). Publication of this article was funded in part by The Pennsylvania State University Libraries Open Access Publishing Fund.

\section{References}

1. Ipser, H., Mikula, A., Katayama, I. Overview: The emf method as a source of experimental thermodynamic data. CALPHAD: Comput. Coupling Phase Diagrams Thermochem. 34 (3), 271 - 278 (2010).

2. Kim, H., Smith, N., Kumar, K., Lichtenstein, T. Electrochemical Separation of Barium into Liquid Bismuth by Controlling Deposition Potentials. Electrochim. Acta. 220, 237 - 244 (2016).

3. Electrometallurgical Techniques for DOE Spent Fuel Treatment: Final Report. National Academy Press. 1 - 116, Washington, D.C, (2000).

4. Simpson, M. F. Projected Salt Waste Production from a Commercial Pyroprocessing Facility. Sci. Technol. Nucl. Install. 2013, 1 - 8 (2013).

5. Lichtenstein, T., Smith, N. D., Gesualdi, J., Kumar, K., Kim, H. Thermodynamic properties of Barium-Bismuth alloys determined by emf measurements. Electrochim. Acta. 228, 628 - 635 (2017).

6. Kim, H., Boysen, D.A., Ouchi, T., Sadoway, D.R. Calcium-bismuth electrodes for large-scale energy storage (liquid metal batteries). J. Power Sources. 241, 239 - 248 (2013).

7. Delcet, J., Delgado-Brune, A., Egan, J.J. Coulometric Titrations Using CaF2 and BaF2 Solid Electrolytes to Study Alloy Phases. Symp. Calc. Phase Diagrams Thermochemistry Alloy Phases. Metallurgical Society of AIME Milwaukee, 275 - 287, (1979).

8. Roine, A., Outokummpu HSC Chemistry 5.1. Chemical Reaction and Equilibrium Software with Extensive Thermochemical Database. (2002).

9. Smith, N.D., Lichtenstein, T., Gesualdi, J., Kumar, K., Kim, H. Thermodynamic Properties of Strontium-Bismuth Alloys Determined by Electromotive Force Measurements. Electrochim. Acta. 225. 584 - 591 (2017).

10. Kim, H., et al. Thermodynamic properties of Calcium-Bismuth alloys determined by emf measurements. Electrochim. Acta. 60, 154 - 162 (2012).

11. Okamoto, H. Ba-Bi (Barium-Bismuth). 2nd ed. ASM International, Materials Park, (1990).

12. Lichtenstein, T., Gesualdi, J., Nigl, T.P., Yu, C.T., Kim, H. Thermodynamic Properties of Barium-Antimony Alloys Determined by Emf Measurements. Electrochim. Acta. (2017).

13. Wagner, C. Limitation of the Use of $\mathrm{CaF}_{2}$ in Galvanic Cells for Thermodynamic Measurements due to the Onset of Electronic Conduction under Reducing Conditions. J. Electrochem. Soc. 115 (9), 933 - 935 (1968). 